\title{
Impact of Active Learning Method on Students Academic Achievement in Physics at Secondary School Level in Pakistan
}

\author{
Kifayat Khan * $\quad$ Muhammad Iqbal Majoka ${ }^{\dagger} \quad$ Khalid Khurshid ${ }^{\ddagger}$ \\ Syed Manzoor Hussain Shah $§$
}

\begin{abstract}
This research aimed to explore the effectiveness of active learning method on students' academic achievement in Physics at secondary school level. A null hypothesis, of no significant difference in the academic achievement of students, taught physics through Active Learning Method (ALM) and Traditional Teaching Method (TTM), was tested to achieve the objectives. For this purpose, the pretest-posttest control group experimental design was used. Eighty (80) Physics students of 9th grade were selected as a sample from Government Centennial Model Higher Secondary School (No.1) District Haripur. These students were equally divided into experimental and control groups $(n=40)$ on the basis of pre-test scores. Experimental and control groups were taught Physics contents through ALM and TTM respectively for twelve (12) weeks. Physics Academic Achievement Test (PAAT) with '0.82' as reliability coefficient was used to collect pretreatment and post-treatment data for measuring the academic achievement of the students. The analyzed data indicated that the experimental group significantly performed better in all the focused learning levels (knowledge, understanding, application, problem-solving, observation, and reasoning) as well as an overall academic achievement than the control group. By these findings, the frequent use of ALM is recommended in the science subjects especially for teaching Physics.
\end{abstract}

Keywords: Effectiveness, active learning method, academic achievement, learning skills, and traditional teaching method.

\section{Introduction}

Learning science requires students' involvement in the activities offering hand-on experiences about various concepts instead defining it verbally or presenting merely in written text. Science education has to accomplish two main objectives that is, to assist students to have an understanding of scientific content material corresponding to their interests, necessities, and capabilities; and to build an understanding of students' scientific concepts via implementation of hands on experiences (Millar, 2004; Scanlon, Morris, Di Paolo, \& Cooper, 2002).

\footnotetext{
*(PhD Research Scholar at Hazara University Mansehra)

Lecturer Department of Education University of Haripur, KP, Pakistan. Email: kifayatkhan@uoh.edu.pk

${ }^{\dagger}$ Assistant Professor, Department of Education, Hazara University, Mansehra.

Email: iqbalmajoka@yahoo.com

‡Associate Professor and Chairman, Department of Education, Bahauddin Zakariya University, Pakistan.

$\S$ Professor and Chairman, Department of Education, Hazara University, Mansehra.
} 
Science subject at secondary level is divided into three branches including Biology, Chemistry, and Physics. In addition, Physics is separated into two sets of knowledge comprising theory and practical. The subject, Physics, is considered as central amongst all the science disciplines (Wenham, 1972). It teaches learners with logical thinking and offers the important theories and principles to understand the mechanism of how the things work. All technology is beholden to physics due to its emphasis on adopting phenomena related to matter and energy and its mutual interaction, which is necessary for the scientific development of the motivated society (Zhaoyao, 2002; Juceviciene \& Karenauskaite, 2004). Physics is the science of observation and measurement. It enables individuals to know and understand the laws of nature specifically and the world generally. This has been acknowledged as fundamental science subject being taught from class 9th to 12th in Pakistan.

Moreover, the learners select Physics as distinct discipline right at this phase seeking to adopt their future careers in basic sciences or engineering, technology, and medicine as pre-professional courses at higher education level. Subsequently, the learners are provided with the theoretical knowledge related to Physics making the students capable to face educational challenges and pre-professional choices next to the secondary school level (Government of Pakistan, 2006). To translate theory into practice, a comprehensive lab practice is of pivotal importance (Trivedi \& Sharma, 2013). In this context, all physics instructors need to have an in-depth understanding of teaching approaches, problemsolving skills, practical work, and students' beliefs to increase their interests in learning (Asikainen \& Hirvonen, 2010). This leads the physics teachers towards the importance of interactive teaching methods.

\section{Literature Review}

\section{Traditional Teaching Approach}

Traditional teaching methods like chalkboard, textbook, lecture, and homework have long been in practice. However, these methods are evaluated as poor and inappropriate in view of contemporary educational requirements (National Commission on Education, 1983). This could be attributed to a number of reasons including but not limited to oneway transfer of knowledge that enhance memorization Gleason et al. (2011); Christie and de Graaff (2017) encourages surface rather than deep learning experience (Gleason et al., 2011; Christie \& de Graaff, 2017); and it encourages bulimic learning (Zorek, Sprague, \& Popovich, 2010). Though it is effective method for transferring huge amount of information to a large number of students Bligh (1999b) yet this approach is characterized as primitive, outdated and traditional one (Taraban, Box, Myers, Pollard, \& Bowen, 2007). Research studies have identified that sole utilization of lecturing generates an inactive and passive learning atmosphere. Instead, pupils? learn better through sharing, acting, responding, and reflecting (Olinger \& Hermanson, 2002).

Over the last 20 years, the focus of the classroom has steadily shifted from a teachercentered approach to a learner-centered approach; by focusing on learning more than 
teaching and students more than instructors (Wohlfarth et al., 2008). Teaching method that engages learners in the class in higher order critical-thinking skills like analysis, synthesis, and evaluation, and has been claimed to be highly effective in improving students' learning, is called active learning (Anderson \& Krathwohl, 2001; Hackathorn et al., 2010).

\section{Theoretical Background of Active Learning}

Active learning is built on the theory of constructivism that has been used to clarify teaching-learning processes and is frequently stated as 'learner-centered instruction'. It has been supposed as paradigm shift from conventional to active learning teaching methods (Kamile, 2007; Tuna \& ncekara, 2010). Dewey (1933/1998) was the philosophical creator of the constructivism, while the philosophers as (Piaget, 1972; Vygotsky, 1980; Bruner, 1990a) are recognized as the chief theorists among the cognitive-constructivists and social-constructivists. Constructivism is the theoretical and organized locus that information passes on through a process of active construction (Mascolo \& Fischer, 2005). This method is chiefly steered by the three features of the constructivist's outlook including; 1) knowledge is constructed by the learner itself; 2) learning is an active process that results from self-constructed meanings formed through linkage between prior knowledge and present learning activity; and 3) learning takes place through social interactions via discussions with others (Bednar, Cunningham, Duffy, \& Perry, 1992; Cooperstein \& Kocevar-Weidinger, 2004). Learning takes place in a social-environment. Subsequently, theoretical growing comes through debating our viewpoints with others, changing our internal thinking in response to that process of mediation (Bednar et al., 1992). In constructivism, the students ask questions from one another to develop their knowledge and make sense out of the world they see (Gunn, 1992).

\section{Active Learning Method}

Active learning according to Bonwell and Eison (1991) is "anything that involves students in doing things and thinking about the things they are doing." The chief component of active learning is students' engagement in activities during learning process. It comprises any kind of technique that engages the learners in the learning process and makes them responsible for their own learning (Yoder \& Hochevar, 2005; Michel, Cater, \& Varela, 2009). Further, active learning is defined as "anything course-related that all students in a class session are called upon to do other than simply watching, listening and taking notes" (Felder \& Brent, 2009). Besides this, learners mostly work in groups and stay busy in debate. As a result, the environment is busy and noisy (Chall, 2009).

Active learning is a two way communique among instructor-learners and learnerslearners. This method has changed the learning atmosphere by shifting the control from the instructor to the students (Gleason et al., 2011; Christie \& de Graaff, 2017) and has placed students at the center of the whole instructional process (Taraban et al., 2007; Kinoshita, Knight, \& Gibbes, 2015). Further, it involves adding small and sporadic tasks to the prevailing procedure McKeachie and Svinicki (2006) and students are given consistent 
opportunities to apply their learning (Armbruster, Patel, Johnson, \& Weiss, 2009). Consequently, this learning approach. Grabinger and Dunlap (1995) offers instructional tasks to make the learners busy in a constant cooperative practice of constructing and restructuring the instructional process that truly reflects the world around them (Kwan \& Wong, 2015).

According to Gleason et al. (2011), active learning is not a sole instructional technique but rather a methodology consisted of manifold conceivable methods. Following the socio-constructivist theories (Niemi, 2002), this method mainly stresses upon strategies based on social context comprising: discussions, dialogues, teamwork, peer-learning, visual based coaching, classroom writing, problem-solving, computer-based tutoring, debates, play, role-play, simulations, sports and peer-teaching, demos, questions/answer techniques, mini-lectures, cooperative learning, and collaborative learning (Sesen \& Tarhan, 2010; Soltanzadeh, Hashemi, \& Shahi, 2013). The students participation Sivan, Leung, Woon, and Kember (2000) is encouraged through conducive environment and an equivalent partnership among the students founded on reciprocal reverence (Drew \& Mackie, 2011; Niemi, Nevgi, \& Aksit, 2016).

The role of the teacher in active learning is to devote larger amount of time facilitating learners improve their understanding and skills for supporting deep learning and a smaller amount of time transferring information for promoting surface learning (Eison, 2010). The teacher must develop a good classroom management in order to promote active learning. A good classroom management comprises four techniques or elements including: content-management, conduct-management, covenant-management, and timemanagement. In general, these techniques wrap all the conditions necessary for effective instructional process (Khan, Khan, \& Majoka, 2011). In addition, these essential features change the classroom pace and are mostly supportive in boosting the learners' participation, motivation, enthusiasm and attention. It increases the effectiveness and applicability of the class (Wingfield \& Black, 2005).

\section{Studies on Active Learning in Physics and Science}

A plethora of research studies have been carried out over the past two decades to see the effectiveness of ALM on students in learning Physics and science at elementary as well as secondary levels round the entire world. In this context, many of the evidences substantiated that ALM works successfully in every discipline.

Several studies on active learning approaches have been conducted nationally. In this context, the Ausubelian teaching method was found more successful in developing academic achievement of the Physics students as compared to traditional teaching method (Safdar, 2013). Further, Hussain, Ahmed, Mubeen, and Tariq (2011) studied the effect of teaching Physics through project method on academic achievement of secondary schools students. The experimental group was observed better than the control group in developing students learning skills (knowledge, comprehension, application) at secondary school level. The results of the study conducted by Khan, Muhammad, Ahmed, Saeed, and Khan (2012) favored activity based teaching against traditional teaching method in improving academic achievement of Physics students of grade 9th at secondary school in 
Khyber Pukhtunkhwah. In addition, Zaman, Choudhary, and Qamar (2015) has compared two instructional strategies and examines its impact on students' performance. The advance organizers strategy was found more effective in comparison to traditional method at secondary school level. Besides, Hussain and Shah (2015) compared inquiry teaching method (ALM) and traditional teaching lecture method. They examined its impacts on students' academic achievement in Physics. The results favored inquiry teaching method.

In global perspective, numerous studies have been conducted on the active learning strategies. In this context, the study of Morgan (1985) on Ausubelian method of teaching was found successful as compared to traditional teaching method. Likewise, Ezeife (1989) experimented to see the influence of teaching Physics via Three Phase Technique (new approach), lecture, and lecture cum demonstration methods on students' performance at secondary school level in Nigeria. The three phase method was found superior in enhancing the performance of students in physics achievement test. Gangoli and Gurumurthy (1995) applied Guided-Open-ended Approach (GOA) and TraditionalLaboratory-Approach (TLA) on a sample of 92 students from higher secondary school level for doing Physics experiments. The Experimental group of GOA was found better in increasing students' intellectual skills like knowledge, understanding, application, and practical skills. However, both the approaches were found same for the development of creative abilities. Adeoye (2010) investigated the effects of cooperative learning strategy and problem-solving strategy on the achievement of Physics students. It was found that students taught Physics through active learning strategies were observed higher in achievement than instructed via traditional method of teaching.

Further, Eryilmaz (2004) examined the effectiveness of peer-instruction enriched- concept test (ALM) and traditional teaching method on students' achievement in Physics. The experimental group instructed via ALM was noticed with better performance which was beyond the control group instructed through the conventional teaching method. Cahyadi (2004) studied the consequences of active learning techniques and in - class demonstration on students' interactive-engagement in Physics course. The active learning method outperformed the conventional lecture in understanding Physics. Kamile (2007) have studied the influences of problem-based active learning on students' concept learning and academic achievement in science education. Pre and posttest treatment control groups design was employed on 50 sampled students. The analyzed data favored the treatment group as compared to traditional teaching methods. Sahin (2010) has investigated the influence of Problem-Based Learning (PBL) on students' achievement in Physics in Turkey. The PBL group $(n=71)$ students overtook the traditional group $(n=71)$ in learning Physics. A research was carried out by Selçuk, Gamze, Sahin, and Açıkgöz (2011) to study the comparative effectiveness of active learning approaches and conventional instruction method on learners' achievements in Physics. To carry out the study, a pre and posttest quasi experimental design was utilized. The results favored the group instructed via explicit learning strategy in promoting achievement in Physics as compared to the control group students. Marušić and Sliško (2012) conducted a study to see the effects of three teaching methods namely Reading-Presenting-Questioning (PRQ), Experimenting and Discussion (ED), and conventional teaching method on students in rising level of 
scientific-thinking in physics. To measure its comparative usefulness, scientific reasoning test was utilized. Both PRQ and ED were found useful in improving level of scientific reasoning.

Furthermore, Saleh (2012) has assessed the effectiveness of the Brain-Based Teaching Approach (BBTA) on students in learning Newtonian Physics at secondary schools in Malaysia. The outcomes preferred active learning method (BBTA) as compared to conventional teaching methods in learning Physics. This study of Shieh (2012) examined the impact of Technology-Enabled Active Learning (TEAL) on learner performance and teacher instruction in physics at high schools level. Through the use of quasi experimental research design, the upshots favored TEAL on students' achievements. The article of O'Grady, Simmie, and Kennedy (2014) investigated the perceptions of pre-service and in-service science teachers concerning active learning, and studies the usefulness of active learning in the Irish secondary level science classroom. The group taught via active learning had a significant effect on learners' academic achievement as compared to the learners taught via conventional methods. In addition, Popoola, Olagoke, and Famiwole (2014) has investigated effects of active learning techniques on the teaching and learning outcomes of students' in basic science in Nigeria. The upshots showed that the activelearning techniques (problem-solving learning technique, cooperative learning technique and discussion learning technique) improved students learning of Basic Science significantly. Selcuk, Caliskan, and Sahin (2013) explored the comparative effectiveness of three teaching methods: problem-based learning, strategic learning (questioning and summarizing) and traditional learning, on learners' achievement in Physics. The experimental group was observed superior to the control group at the end.

Likewise, the investigators Ojediran, Oludipe, and Ehindero (2014), examined the impact of Laboratory-Based Instructional Intervention (LBII) on low performing secondary students learning outcomes in Physics. The laboratory-based instructional intervention (active learning method) outperformed performance in the achievement in Physics than Conventional Teaching Method (CTM). The study of Mankilik and Ofodile (2015) has examined the influences of Hybrid Active Learning Strategy (HALS) on students' understanding of direct current conception in Physics at secondary school level in Nigeria. A pre and posttest treatment-control groups design was employed. The outcomes exhibited that the group exposed to HALS outperformed meaningfully than the group exposed to traditional method in learning Physics' concepts. Georgiou and Sharma (2014) have examined the effect of Interactive-Lecture-Demonstrations (ILD)/active learning and nonILD lectures on students understanding the concepts of thermodynamics in Physics at high school. The finding revealed that ILDs help students in understanding concepts and provide opportunities for scientific reasoning. In addition, the study of Kim (2016) showed that the Inquiry-Based-Science \& Technology-Enrichment-Program (InSTEP) was more effective in increasing learners' content knowledge of science than conservative teaching method. The study conducted by Savinainen, Mäkynen, Nieminen, and Viiri (2017) revealed that Teaching-Learning-Sequence (TLS) method was superior to conventional teaching method on learner understanding of Newton's third law of motion in Physics. However, Problem-Based Learning (PBL) was not found superior to traditional teaching method in improving students' academic achievement at high school level 
(Wilder, 2015). The study of Peşman and Özdemir (2012) found no evidence, that learning cycle strategy is better than the conventional teaching method.

In Pakistan, the innovative teaching strategies are not much accepted for teaching due to mismatch with prevailing assessment methods in classroom Halai (2012) as compared to global perspective. Besides, there is scarce research on active learning methods and teaching strategies in the science classroom. Therefore, there is dire need to test and introduce active learning strategies in classroom, especially for teaching science subjects. Considering the importance of Physics among science subjects, a study was conducted to examine the impact of Active Learning Method (ALM) on the academic achievement of the students in learning physics at secondary school level in Pakistan. The objectives of this study were:

1. To compare the experimental and control groups students over pre-test of academic achievement in learning (knowledge, understanding, application, problem solving, observation, reasoning) Physics at secondary school level.

2. To find the impact of ALM on academic achievement of the students in learning (knowledge, understanding, application, problem solving, observation, reasoning) Physics at secondary level.

To achieve the objectives of the study, the following two null hypotheses were tested.

1. There is no significant difference between the experimental and control groups students in the pre-test of academic achievement in learning (knowledge, understanding, application, problem solving, observation, reasoning) Physics at secondary school level.

2. There is no significant difference in posttest learning skills of academic achievement of students taught Physics through Active Learning Method (ALM), and those taught through Traditional Teaching Method (TTM) of grade 9th at secondary school level.

\section{Significance of the Study}

Owing to the scarce research studies on ALM in Pakistan, this experimental study could be of greater importance. ALM is a novel paradigm that could be more helpful for teachers as well as students in enhancing their teaching and learning capabilities in contrast to the conventional teaching methodologies. This research can assist as a source of direction to the educational institutions' heads and the education officers to improve capacity of science teacher through organizing workshops and science teachers' trainings on ALM. This study might be helpful for future researcher to perform alike studies by spreading it to other levels (higher secondary, elementary, primary) either in separation or in combination with other teaching techniques and methods. 


\section{Research Methodology}

To examine the effect of ALM, the pretest posttest equivalent group design was adopted, which according to Campbell and Stanley (1963); Gay (1999) is the strongest and the true experimental design since it controls majority of internal validity sources (history, maturation, testing, instrumentation, statistical regression, differential selection, experimental mortality and subjects selection). These sources might produce adverse effects if not controlled (Tabassum \& Farooq, 2004; Raninga, 2009).

After seeking feasibility of conducting experiment, eighty (80) 9th grade students from the class of Physics at Government Centennial Model Higher Secondary School (GCMHSS) No.1 (Boys) Haripur, were chosen as sample of the study. These students were distributed equally into two groups (40 each) on the basis of pre-test PAAT and randomly assigned to the experimental and control group. For the active learning to have a substantial effect on students learning outcomes, the classroom should not exceed forty (40) students at all (Mulongo, 2013).

Pretreatment and post treatment data were collected through Physics Academic Achievement Test (PAAT). This test was prepared from chapters (Turning Effect of Force, Properties of Matter, Thermal Properties of Matter, and Transfer of Heat) of Physics text-book for grad 9th Peshawar (National Science Curriculum, 2006). The PAAT comprised of hundred (100) multiple choices test items in six learning skills. It included 17 questions about knowledge, understanding, application, problem solving, and observation skills respectively while for reasoning skills, 15 questions were included. To confirm face validity and content validity of the test, expert opinions of the researchers and Physics teachers (professors, lecturers, subject specialists, senior science teacher, and test items analysts) were sorted out. The PAAT test was piloted on sixty (60) grade 9th Physics students in Working Folk Grammar School (Boys Branch), Haripur; other than the sampled school. Following the pilot study, some ambiguous questions were rephrased to give greater clarity while others were discarded and replaced by new questions. Reliability coefficient of the test was calculated as 0.82 .

Thirty (30) lessons, each of seventy (70) minutes, were prepared to provide training via ALM and TTM. The same school science teacher was trained on these teaching methods for two weeks. The students were randomly distributed into experimental and control group on the bases of equal mean scores (42.15 and 42.03), obtained as a result of the pre-test PAAT conducted prior to the experiment. The PAAT responses were gathered via answer sheets and marked via a pre-prepared key. To make the environment harmonious, both the experimental and control groups were taught through ALM and TTM in the classroom. The researcher visited the school in order to observe the experimental process and provide feedback where necessary. The study lasted for 16 weeks (four months). To find the difference in students' performance, the collected data through post test PAAT were analyzed using mean scores, standard deviations, and t-tests through the utilization of statistical package for social science. 


\section{Data Analysis and Interpretation}

The data gathered using pre and post-test PAAT were examined and interpreted. The tables concerning the experimental and control group mean scores differences in learning Physics (learning skills) over academic achievement are given below:

\begin{tabular}{|c|c|c|c|c|c|c|c|}
\hline Learning Skills & Groups & $\mathbf{N}$ & $\mathbf{M}$ & SD & SEM & $t$ & $\mathbf{P}$ \\
\hline \multirow{2}{*}{ Knowledge } & Exp & 40 & 9.38 & 2.32 & 0.37 & \multirow{2}{*}{0.047} & \multirow{2}{*}{0.963} \\
\hline & Con & 40 & 9.35 & 2.44 & 0.39 & & \\
\hline \multirow{2}{*}{ Understanding } & Exp & 40 & 7.83 & 2.00 & 0.32 & \multirow{2}{*}{0.101} & \multirow{2}{*}{0.920} \\
\hline & Con & 40 & 7.79 & 2.41 & 0.38 & & \\
\hline \multirow{2}{*}{ Application } & Exp & 40 & 7.83 & 2.04 & 0.32 & \multirow{2}{*}{0.056} & \multirow{2}{*}{0.955} \\
\hline & Con & 40 & 7.85 & 1.96 & 0.31 & & \\
\hline \multirow{2}{*}{ Problem Solving } & Exp & 40 & 6.60 & 1.71 & 0.27 & \multirow{2}{*}{0.000} & \multirow{2}{*}{1.000} \\
\hline & Con & 40 & 6.60 & 1.88 & 0.30 & & \\
\hline \multirow{2}{*}{ Observation } & Exp & 40 & 5.63 & 2.01 & 0.32 & \multirow{2}{*}{0.174} & \multirow{2}{*}{0.863} \\
\hline & Con & 40 & 5.57 & 1.85 & 0.29 & & \\
\hline \multirow{2}{*}{ Reasoning } & Exp & 40 & 4.90 & 1.86 & 0.29 & \multirow{2}{*}{0.000} & \multirow{2}{*}{1.000} \\
\hline & Con & 40 & 4.90 & 1.93 & 0.31 & & \\
\hline
\end{tabular}

Table 1 shows that for $\mathrm{P}>0.05$, the difference between mean scores of the experimental group and control group is not significant. Further, for every factor of learning skills (knowledge, understanding, application, problem solving, observation, reasoning), the experimental group mean scores $(9.38,7.83,7.83,6.60,5.63$, and 4.90) and the control group mean scores $(9.35,7.79,7.85,6.60,5.57$ and 4.90$)$ are found same at the pretest PAAT comparison. The null hypothesis H01 is completely accepted. Therefore, students of both groups were same in academic achievement at the start of experiment. This can be easily shown with the help of column chart as shown below.

\section{Figure 1}

Experimental and control groups comparison in learning physics over pre-test PAAT

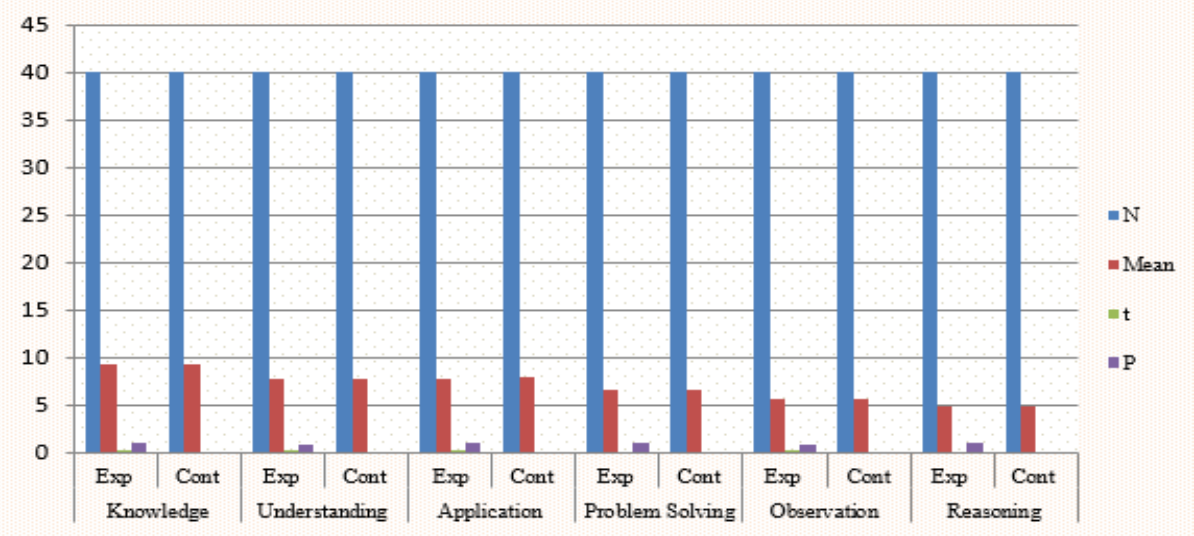




\section{Table 2}

Experimental and control groups comparison

for knowledge skill over posttest PAAT

\begin{tabular}{lcccccc}
\hline Groups & N & M & SD & SEM & t & P \\
\hline Exp & 40 & 13.57 & 2.32 & 0.37 & \multirow{2}{*}{10.55} & 0.000 \\
Con & 40 & 8.120 & 2.30 & 0.36 & &
\end{tabular}

Table 2 specifies the mean scores, standard deviations, and standard error of mean for post test PAAT comparison of the experimental group ( $\mathrm{ME}=13.57, \mathrm{SD}=2.32, \mathrm{SEM}=0.37$ ) and control group $(\mathrm{MC}=8.12, \mathrm{SD}=2.30, \mathrm{SEM}=0.36$ ) respectively. The difference between the two groups is statistically significant since $\mathrm{p}<0.05$. So, the null hypothesis $H_{2}$ is rejected. The mean score of the experimental group is greater than the mean score of the control group students in learning Physics over knowledge skill.

Table 3
$\begin{aligned} & \text { Experimental and control groups comparison } \\
& \text { for understanding skill over }\end{aligned}$ posttest PAAT
\begin{tabular}{lcccccc} 
Groups & $\mathbf{N}$ & $\mathbf{M}$ & SD & SEM & $\mathbf{t}$ & $\mathbf{P}$ \\
\hline Exp & 40 & 13.15 & 1.97 & 0.31 & & \\
Con & 40 & 9.020 & 2.68 & 0.42 & & 0.000 \\
\end{tabular}

Table 3 indicates the mean scores, standard deviations, and standard error of mean for post test PAAT comparison of the experimental group ( $\mathrm{ME}=13.15, \mathrm{SD}=1.97, \mathrm{SEM}=0.31$ ) and control group $(\mathrm{MC}=9.02, \mathrm{SD}=2.68, \mathrm{SEM}=0.42)$ respectively. The difference between the two groups is statistically significant since $\mathrm{p}<0.05$. So, the null hypothesis $\mathrm{H}_{2}$ is rejected. The mean score of the experimental group is greater than the mean score of the control group students in learning physics over understanding skill.

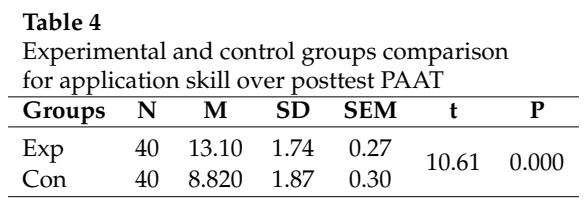

Table 4 reveals the mean scores, standard deviations, and standard error of mean for post test PAAT comparison of the experimental group ( $\mathrm{ME}=13.10, \mathrm{SD}=1.74, \mathrm{SEM}=0.27$ ) and control group $(\mathrm{MC}=8.82, \mathrm{SD}=1.87, \mathrm{SEM}=0.30$ ) respectively. The difference between the two groups is statistically significant since $\mathrm{p}<0.05$. So, the null hypothesis $H_{2}$ is rejected. The mean score of the experimental group is greater than the mean score of the control group students in learning Physics over application skill.

Table 5

Experimental and control groups comparison

for problem solving skill over posttest PAAT

\begin{tabular}{lcccccc}
\hline Groups & $\mathbf{N}$ & $\mathbf{M}$ & SD & SEM & $\mathbf{t}$ & $\mathbf{P}$ \\
\hline Exp & 40 & 12.15 & 2.06 & 0.33 & & \\
Con & 40 & 7.620 & 2.59 & 0.41 & & 0.000 \\
\hline
\end{tabular}


Table 5 displays the mean scores, standard deviation, and standard error of mean for post test PAAT comparison of the experimental group $(\mathrm{ME}=12.15, \mathrm{SD}=2.06, \mathrm{SEM}=0.33)$ and control group $(\mathrm{MC}=7.62, \mathrm{SD}=2.59, \mathrm{SEM}=0.41)$ respectively. The difference between the two groups is statistically significant since $\mathrm{p}<0.05$. So, the null hypothesis $\mathrm{H}_{2}$ is rejected. The mean score of the experimental group is greater than the mean score of the control group students in learning Physics over problem solving skill.

\begin{tabular}{|c|c|c|c|c|c|c|}
\hline $\begin{array}{l}\text { Table } 6 \\
\text { Experim } \\
\text { for obser }\end{array}$ & ntal & $\begin{array}{l}\text { and cor } \\
\text { a skill }\end{array}$ & $\begin{array}{l}\text { trol } \mathrm{g} \\
\text { jer } \mathrm{pc}\end{array}$ & $\begin{array}{l}\text { oups co } \\
\text { ttest } P\end{array}$ & $\begin{array}{l}\text { npari } \\
\text { AT }\end{array}$ & \\
\hline Groups & $\mathbf{N}$ & M & SD & SEM & $t$ & $\mathbf{P}$ \\
\hline Exp & 40 & 11.70 & 2.39 & 0.38 & 1100 & $0 \cap 0 \cap 0$ \\
\hline Con & 40 & 5.850 & 2.35 & 0.37 & 11.05 & 0.000 \\
\hline
\end{tabular}

Table 6 shows the mean scores, standard deviation, and standard error of mean for post test PAAT comparison of the experimental group ( $\mathrm{ME}=11.70, \mathrm{SD}=2.39, \mathrm{SEM}=0.38$ ) and control group $(\mathrm{MC}=5.85, \mathrm{SD}=2.35, \mathrm{SEM}=0.37$ ) respectively. The difference between the two groups is statistically significant since $\mathrm{p}<0.05$. So, the null hypothesis $\mathrm{H}_{2}$ is rejected. The mean score of the experimental group is greater than the mean score of the control group students in learning physics over observation skill.

Table 7
Experimental and control groups comparison
for reasoning skill over posttest PAAT
\begin{tabular}{lcccccc} 
Groups & $\mathbf{N}$ & $\mathbf{M}$ & SD & SEM & $\mathbf{t}$ & $\mathbf{P}$ \\
\hline Exp & 40 & 9.82 & 2.69 & 0.43 & & \\
Con & 40 & 4.57 & 2.71 & 0.43 & & 0.000 \\
\hline
\end{tabular}

Table 7 displays the mean scores, standard deviation, and standard error of mean for post test PAAT comparison of the experimental group ( $\mathrm{ME}=9.82, \mathrm{SD}=2.69, \mathrm{SEM}=0.43)$ and control group $(\mathrm{MC}=4.57, \mathrm{SD}=2.71, \mathrm{SEM}=0.43)$ respectively. The difference between the two groups is statistically significant since $\mathrm{p}<0.05$. So, the null hypothesis $H_{2}$ is rejected. The mean score of the experimental group is greater than the mean score of the control group students in learning Physics with respect to the reasoning skills.

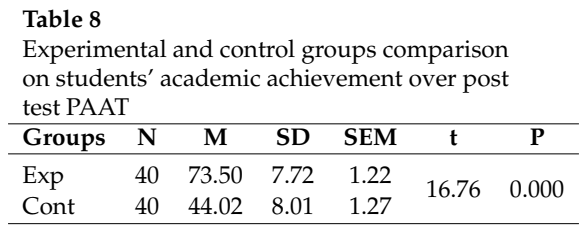

Table 8 reveals the mean scores, standard deviation, and standard error of mean for posttest PAAT comparison of the experimental group ( $\mathrm{ME}=73.50, \mathrm{SD}=7.72, \mathrm{SEM}=1.22$ ) and control group $(\mathrm{MC}=44.02, \mathrm{SD}=8.01, \mathrm{SEM}=1.27)$. The difference between the two groups is statistically significant since $\mathrm{p}<0.05$. So, the null hypothesis $\mathrm{H}_{2}$ is therefore, rejected. The mean score of the experimental group is significantly greater than the mean 
score of the control group students on students' academic achievement in learning Physics with respect to the reasoning.

\section{Discussion}

This discussion is grounded on several earlier studies carried out on active learning for the subject of Physics specifically and on the subject of science generally. For tables (2, $3,4,5,6,7)$, the value of $\mathrm{p}<0.05$ level of significance, so, there is statistically significant difference between mean scores of the experimental and control group at post test PAAT comparison. The null hypothesis $H_{2}$ is, therefore, rejected. Moreover, for every element of learning skill (knowledge, understanding, application, problem solving, observation, and reasoning), the mean scores of experimental group $\operatorname{ME}(13.57,13.15,13.10,12.15$, and $11.70)$, is greater than the corresponding mean scores of control group $\mathrm{MC}(8.12,9.02,8.82$, $7.62,5.85$, and 4.57$)$ students respectively. The entire statistics indicates that students of the experimental group were found superior to their respective control group students in learning Physics of grade IX. These findings are in agreement with the results of the studies conducted (Gangoli \& Gurumurthy, 1995; Hussain et al., 2011; Khan et al., 2012).

For table 8 , the value of $\mathrm{p}<0.05$ level, so the difference is significant statistically. The hypothesis $\mathrm{H}_{2}$ is rejected. The mean score of the experimental group (73.50) is greater than the corresponding mean score of the control group (44.02). Thus, students of the experimental group are found better than their respective control group in academic achievement. These findings are in agreement with the outcomes of the studies carried out countrywide (Khan et al., 2012; Zaman et al., 2015; Hussain \& Shah, 2015). Further, these outcomes also agree with the results of the studies carried out globally (Saleh, 2012; O'Grady et al., 2014; Popoola et al., 2014; Mankilik \& Ofodile, 2015; Kim, 2016; Savinainen et al., 2017). However, these results contrite to the work of the researchers (Gangoli \& Gurumurthy, 1995; Peşman \& Özdemir, 2012; Wilder, 2015).

\section{Limitations of the Study}

The first limitation of the study was a "small sample size" of eighty (80) Physics students of grade 9th at secondary school of District Haripur. This limits the generalization of the findings. Future, researchers should utilize larger samples wherein the impact of ALM on academic achievement in Physics can be studied. The second limitation of the study is the "lengthy class". The students were taught in a class for duration of seventy (70) minutes, which might effects the performance of the students due to the factors of boredom and fatigue. Re-scheduling the class duration may overcome these factors. It may enhance the influence of ALM on students' academic work. The third limitation is the school "Physics laboratory". At secondary level, there was no separate Physics Laboratory where handson-activities and practical work etc., could be performed; therefore, both the groups were taught in the usual classrooms to meet the needs. Theses might have some effects on the study effectiveness. Therefore, in future such kinds of studies may be conducted in the rich environment of Physics lab to study its effectiveness. The fourth limitation may be as results of "same location and same gender (male)." No care has been taken for the impact 
of gender differences (male/female) and location (urban/rural) which might effects the study findings. Therefore, future studies may be conducted to see the effectiveness of ALM on academic achievement in Physics at grade 9th keeping the location and gender differences in mind.

\section{Conclusion}

Subject to the limitations stated above, the study guides towards the subsequent conclusions. It was concluded that learners imparted Physics via ALM attained high academic achievement than learners imparted via TTM in Physics of 9th grade at secondary school level. ALM was more effective than TTM in growing learning levels like knowledge, understanding, application, problem solving, observation, and reasoning of the grade 9th Physics students at secondary school level.

\section{Recommendations}

The ALM method is essential to be integrated in all schools because it is appropriate for developing learning levels, learning skills and academic achievement of the students. Further, the educational authorities at national, provincial, district, and school level along with collaboration of private educational societies, may conduct in-service teachers trainings and workshops, refresher courses and seminars for working Physics teachers on ALM methodologies, with the intention of utilizing it in their routine practice to improve students' performance. Active learning method is proved useful in developing students' academic achievement in Physics at secondary school level of district Haripur Khyber, Pakhtunkhwah Pakistan. Consequently, to obtain a more global perspective and improve generalizability, more schools and countries may repeat the same study because the cultures and educational systems variations can influence the outcomes of the study. 


\section{References}

Adeoye, F. A. (2010). Effects of problem-solving and cooperative learning strategies on senior secondary school students' achievement in physics. Journal of Theory $\mathcal{E}$ Practice in Education (JTPE), 6(2), 235-266.

Anderson, L. W., \& Krathwohl, D. R. (2001). A taxonomy for learning, teaching and assessing: A revision of Bloom's taxonomy. New York: Longman.

Armbruster, P., Patel, M., Johnson, E., \& Weiss, M. (2009). Active learning and studentcentered pedagogy improve student attitudes and performance in introductory biology. CBE-Life Sciences Education, 8(3), 203-213.

Asikainen, M. A., \& Hirvonen, P. E. (2010). Finnish cooperating physics teachers' conceptions of physics teachers' teacher knowledge. Journal of Science Teacher Education, 21(4), 431-450.

Bednar, A. K., Cunningham, D., Duffy, T. M., \& Perry, J. D. (1992). Theory into practice: How do we link. Englewood, CO: Libraries Unlimited, Inc.

Bligh, D. (1999b). What's the use of lectures? New York, NY: John Wiley \& Sons.

Bonwell, C. C., \& Eison, J. A. (1991). Active learning: Creating excitement in the classroom. 1991 ASHE-ERIC Higher Education Reports. The George Washington University.

Bruner, J. (1990a). Acts of meaning. Cambridge, MA: Harvard University Press.

Cahyadi, V. (2004). The effect of interactive engagement teaching on student understanding of introductory physics at the Faculty of Engineering, University of Surabaya, Indonesia. Higher Education Research \& Development, 23(4), 455-464.

Campbell, D. T., \& Stanley, J. C. (1963). Experimental and quasi-experimental designs for research on teaching. Chicago: Rand-McNally.

Chall, J. S. (2009). The academic achievement challenge: What really works in the classroom? London: Guilford press.

Christie, M., \& de Graaff, E. (2017). The philosophical and pedagogical underpinnings of active learning in engineering education. European Journal of Engineering Education, 42(1), 5-16.

Cooperstein, S. E., \& Kocevar-Weidinger, E. (2004). Beyond active learning: a constructivist approach to learning. Reference Services Review, 32(2), 141-148.

Dewey, J. (1933/1998). How we think. Boston, MA: Houghton Mifflin Company.

Drew, V., \& Mackie, L. (2011). Extending the constructs of active learning: Implications for teachers' pedagogy and practice. Curriculum Journal, 22(4), 451-467.

Eison, J. (2010). Using active learning instructional strategies to create excitement and enhance learning. , 1-20.

Eryilmaz, H. (2004). The effect of peer instruction on high school students' achievement and attitudes toward physics. The Middle East Technical University.

Ezeife, A. N. (1989). The impact of the three-phase instruction technique on students' performance in physics. Educational Research, 31(3), 227-231.

Felder, R. M., \& Brent, R. (2009). Active learning: An introduction. ASQ Higher Education Brief, 2(4), 1-5.

Gangoli, S., \& Gurumurthy, C. (1995). A study of the effectiveness of a guided openended approach to physics experiments. International Journal of Science Education, 
17(2), 233-241.

Gay, A. S. (1999). Is problem solving in middle school mathematics "normal"? Middle School Journal, 31(1), 41-47.

Georgiou, H., \& Sharma, M. (2014). Does using active learning in thermodynamics lectures improve students' conceptual understanding and learning experiences? European Journal of Physics, 36(1), 15-20.

Gleason, B. L., Peeters, M. J., Resman-Targoff, B. H., Karr, S., McBane, S., Kelley, K., ... Denetclaw, T. H. (2011). An active-learning strategies primer for achieving abilitybased educational outcomes. American Journal of Pharmaceutical Education, 75(9), 186.

Government of Pakistan. (2006). Grades IX-X, National Physics Curriculum, Ministry of Education Islamabad.

Grabinger, R. S., \& Dunlap, J. C. (1995). Rich environments for active learning: A definition. ALT-J, 3(2), 5-34.

Gunn, B. (1992). The courage to be a constructivist. The Constructivist Classroom, 57(3), $18-24$.

Hackathorn, J., Solomon, E., Tennial, R., Garczynski, A., Blankmeyer, K., Gebhardt, K., \& Anthony, J. (2010). You get out what you put in: Student engagement affects assessment. In Poster presentation: Best Practices in Assessment Conference: Atlanta, GA. Atlanta, GA.

Halai, N. (2012). Developing understanding of innovative strategies of teaching science through action research: A qualitative meta-synthesis from Pakistan. International Journal of Science and Mathematics Education, 10(2), 387-415.

Hussain, S., Ahmed, S., Mubeen, S., \& Tariq, S. (2011). The effectiveness of teaching physics through project method on academic achievement of students at secondary level-a case study. Journal of Education and Practice, 2(8), 28-34.

Hussain, S., \& Shah, M. H. (2015). Effect of inquiry teaching method on academic achievements of male students in subject of physics: A case study. European Academic Research, II (12). ISSN 2286-4822, 44(3), 331-343.

Juceviciene, P., \& Karenauskaite, V. (2004). Learning environment in physics: The context of double paradigm shift. Paper presented at the European Conference on Educational Research, University of Crete.

Kamile, A. (2007). Active learning. Izmir: Bilis Press.

Khan, Khan, M., \& Majoka, M. (2011). Gender difference in classroom management strategies at secondary level. Interdisciplinary Journal of Contemporary Research in Business, 3(3), 580-588.

Khan, Muhammad, N., Ahmed, M., Saeed, F., \& Khan, S. A. (2012). Impact of activitybased teaching on students' academic achievements in physics at secondary level. Academic Research International, 3(1), 146-156.

Kim, H. (2016). Inquiry-based science and technology enrichment program for middle school-aged female students. Journal of Science Education E Technology, 25(2), 174186.

Kinoshita, T. J., Knight, D. B., \& Gibbes, B. (2015). The positive influence of active learning in a lecture hall: An analysis of normalised gain scores in introductory environmental engineering. Innovations in Education and Teaching International, 54(3), 1-10. 
Kwan, Y. W., \& Wong, A. F. (2015). Effects of the constructivist learning environment on students' critical thinking ability: Cognitive and motivational variables as mediators. International Journal of Educational Research, 70, 68-79.

Mankilik, M., \& Ofodile, U. C. (2015). Effects of hybrid active learning strategy on students' understanding of direct current electricity concepts in Nigerian secondary schools. International Journal of Learning, Teaching and Educational Research, 13(2), 7787.

Marušić, M., \& Sliško, J. (2012). Influence of three different methods of teaching physics on the gain in students' development of reasoning. International Journal of Science Education, 34(2), 301-326.

Mascolo, M., \& Fischer, K. (2005). Constructivist theories. Cambridge Encyclopedia of Child Development, 49-63.

McKeachie, W. J., \& Svinicki, M. (2006). Mckeachie's teaching tips. MA: Houghton Mifflin.

Michel, N., Cater, J. J., \& Varela, O. (2009). Active versus passive teaching styles: An empirical study of student learning outcomes. Human Resource Development Quarterly, 20(4), 397-418.

Millar, R. (2004). The role of practical work in the teaching and learning of science. High school science laboratories: Role and vision. National Academy of Science, Washington, DC.

Morgan, B. S. (1985). The effects of two types of prelaboratory exercises when used as advance organizers on student achievement and attitudes in an introductory biology laboratory course. (Doctoral dissertation).

Mulongo, G. (2013). Effect of active learning teaching methodology on learner participation. Journal of Education and Practice, 4(4), 157-168.

National Commission on Education. (1983). A Nation at Risk, Washington, D.C., U.S. Department of Education.

National Science Curriculum. (2006). Grades IX-X, Government of Pakistan, Ministry of Education Islamabad.

Niemi, H. (2002). Active learning-a cultural change needed in teacher education and schools. Teaching and Teacher Education, 18(7), 763-780.

Niemi, H., Nevgi, A., \& Aksit, F. (2016). Active learning promoting student teachers' professional competences in Finland and Turkey. European Journal of Teacher Education, 39(4), 471-490.

O'Grady, A., Simmie, G. M., \& Kennedy, T. (2014). Why change to active learning? Preservice and in-service science teachers' perceptions. European Journal of Teacher Education, 37(1), 35-50.

Ojediran, I. A., Oludipe, D. I., \& Ehindero, O. J. (2014). Impact of laboratory-based instructional intervention on the learning outcomes of low performing senior secondary students in physics. Creative Education, 5(4), 197-206.

Olinger, D. J., \& Hermanson, J. C. (2002). Integrated thermal-fluid experiments in WPI's discovery classroom. Journal of Engineering Education, 91(2), 239-243.

Peşman, H., \& Özdemir, Ö. F. (2012). Approach-method interaction: The role of teaching method on the effect of context-based approach in physics instruction. International Journal of Science Education, 34(14), 2127-2145.

Piaget, J. (1972). The psychology of the child. New York: Basic Books. 
Popoola, A. A., Olagoke, A. M., \& Famiwole, R. O. (2014). Active learning: Evidence from basic science classes. Journal of Educational Research and Studies, 2(1), 1-6.

Raninga, N. C. (2009). The effectiveness of different revision approaches in science on achievement and retention of learners having different learning styles (Unpublished doctoral dissertation). Saurashtra University.

Safdar, M. (2013). Meaningful learning and rote learning in physics: A comparative study in city Jhelum (Pakistan). Middle Eastern \& African Journal of Educational Research, 6, 60-77.

Sahin, M. (2010). The impact of problem-based learning on engineering students' beliefs about physics and conceptual understanding of energy and momentum. European Journal of Engineering Education, 35(5), 519-537.

Saleh, S. (2012). The effectiveness of brain-based teaching approach in dealing with the problems of students' conceptual understanding and learning motivation towards physics. Educational Studies, 38(1), 19-29.

Savinainen, A., Mäkynen, A., Nieminen, P., \& Viiri, J. (2017). The effect of using a visual representation tool in a teaching-learning sequence for teaching Newton's third law. Research in Science Education, 1(47), 119-135.

Scanlon, E., Morris, E., Di Paolo, T., \& Cooper, M. (2002). Contemporary approaches to learning science: technologically-mediated practical work. Studies in Science Education, 38(1), 73-114.

Selcuk, G. S., Caliskan, S., \& Sahin, M. (2013). A comparison of achievement in problembased, strategic and traditional learning classes in physics. International Journal on New Trends in Education and Their Implications, 4(1), 154-164.

Selçuk, S., Gamze, Sahin, M., \& Açıkgöz, K. Ü. (2011). The effects of learning strategy instruction on achievement, attitude, and achievement motivation in a physics course. Research in Science Education, 41(1), 39-62.

Sesen, B. A., \& Tarhan, L. (2010). Promoting active learning in high school chemistry: Learning achievement and attitude. Procedia-Social and Behavioral Sciences, 2(2), 2625-2630.

Shieh, R. S. (2012). The impact of technology-enabled active learning (teal) implementation on student learning and teachers' teaching in a high school context. Computers $\mathcal{E}$ Education, 59(2), 206-214.

Sivan, A., Leung, R. W., Woon, C.-c., \& Kember, D. (2000). An implementation of active learning and its effect on the quality of student learning. Innovations in Education and Teaching International, 37(4), 381-389.

Soltanzadeh, L., Hashemi, S. R. N., \& Shahi, S. (2013). The effect of active learning on academic achievement motivation in high schools students. Archives of Applied Science Research, 5(6), 127-131.

Tabassum, R., \& Farooq, R. A. (2004). Effect of Computer Assisted Instruction (CAI) on the Secondary School Students Achievement in Science (Ph.D thesis). Journal of Education for Business, 81, 119-125.

Taraban, R., Box, C., Myers, R., Pollard, R., \& Bowen, C. W. (2007). Effects of activelearning experiences on achievement, attitudes, and behaviors in high school biology. Journal of Research in Science Teaching, 44(7), 960-979. 
Trivedi, R., \& Sharma, M. (2013). A study of students' attitude towards physics practical at senior secondary level. International Journal of Scientific and Research Publications, $3(8), 1-4$.

Tuna, F., \& ncekara, S. (2010). Skills in geography education. In Concepts and Changes in Geography Education, ed. R. Ozey, and S. ncekara,. Ankara: Pegem Akademi.

Vygotsky, L. S. (1980). Mind in society: The development of higher psychological processes. Cambridge, MA: Harvard University Press.

Wenham, E. J. (1972). Physics, concepts and models. Addison-Wesley.

Wilder, S. (2015). Impact of problem-based learning on academic achievement in high school: A systematic review. Educational Review, 67(4), 414-435.

Wingfield, S. S., \& Black, G. S. (2005). Active versus passive course designs: The impact on student outcomes. Journal of Education for Business, 81(2), 119-123.

Wohlfarth, D., Sheras, D., Bennett, J. L., Simon, B., Pimentel, J. H., \& Gabel, L. E. (2008). Student perceptions of learner-centered teaching. Insight: A Journal of Scholarly Teaching, 3, 67-74.

Yoder, J. D., \& Hochevar, C. M. (2005). Encouraging active learning can improve students' performance on examinations. Teaching of Psychology, 32(2), 91-95.

Zaman, T., Choudhary, F., \& Qamar, A. (2015). Advance organizers help to enhance learning and retention. International Journal of Humanities Social Sciences and Education, 2(3), 45-53.

Zhaoyao, M. (2002). Physics education for the 21st century: Avoiding a crisis. Physics Education, 37(1), 18-24.

Zorek, J. A., Sprague, J. E., \& Popovich, N. G. (2010). Bulimic learning. American Journal of Pharmaceutical Education. Article 157, 74(8). 